\title{
NON MUSLIM JANGAN DISEBUT KAFIR, SEBUT SAJA MUWATHINUN (WARGA NEGARA)
}

\author{
Oleh: M. Jamil ${ }^{1}$
}

Akhir-akhir ini Indonesia dihebohkan dengan adanya gagasan pelarangan penyebutan non muslim dengan sebutan kafir. Keheboan tersebut bermula dengan adanya gagasan yang diungkapkan oleh Nahdlatul Ulama (NU) melalui Munasnya yang terselenggara belum lama ini di Kota Banjar, Jawa Barat.

Sebenarnya Hasil Munas NU memaknai kata 'kafir' yang kerap menjadi celoteh dalam konteks bernegara dan demokrasi. Disadari atau tidak, kata Kafir bisa ditafsirkan bukan sekadar non-muslim, tapi dalam konteks negara. Hal ini menguak dalam Bahtsul Masail Maudlu'iyyah (tematik) tentang "Negara, Kewarganegaraan, Hukum Negara dan Perdamaian" saat Munas NU kata kafir sebaiknya tidak ada.

Hasil Munas NU menilai, sebagai dasar negara Pancasila berhasil menyatukan rakyat Indonesia yang plural, baik dari sudut etnis dan suku maupun agama dan budaya. Di bawah payung Pancasila, seluruh warga negara itu setara; semisal si A tak lebih unggul dari si B kalau dilihat berdasarkan suku, etnis, juga agama.

Setiap warga negara memiliki status kewargaan penuh dengan hak dan kewajiban yang setara, terlepas dari perbedaan latar belakang agama. Kategori muslim dan kafir tidak relevan dalam status kewarganegaraan. Produk undangundang atau kebijakan negara yang lahir dari proses politik moderen mengikat seluruh warga negara. Jika tidak bertentangan dengan nilai-nilai Islam, wajib ditaati secara syari'at (mulzim syar'i). (Yahya Cholil Staquf).

\footnotetext{
${ }^{1}$ Ketua Umum Pusat Studi Mahasiswa Pascasarjana (PUSMAJA) Mbojo-Yogyakarta Periode 2015-2017 | | Ketua II Bagian Eksternal Dewan Pimpinan Cabang Perhimpunan Mahasiswa Hukum Indonesia Daerah Istimewa Yogyakarta (DPC PERMAHI DIY) Periode 2012-2014 | Email: jamilncera@gmail.com | FB/Youtube/IG/Twitter: @MJAMILSH | Website: http://www.mjamil.my.id.
} 
Pemaknaan secara konstitusi tentang siapa saja yang disebut dengan warga negara dapat dilihat selengkapnya dalam Pasal 1 Undang-Undang Nomor 12 Tahun 2006 Tentang Kewarganegaraan Republik Indonesia (UU Kewarganegaraan).

Keputusan Munas NU hanya sekedar memperkokoh atau mendaur ulang gagasan besar yang pernah dilakukan sang putra padang pasir Nabi agung Muhammad SAW dengan Piagam Madinah dalam rangka menyatukan seluruh rakyat Madinah pada saat itu. Inti terpenting dalam Piagam Madinah tersebut menegaskan bahwa seluruh penduduk Madinah adalah satu kesatuan bangsa/umat -yang berdaulat di hadapan bangsa/umat lainnya- tanpa diskriminasi pihak lain diluar Islam. Hal ini bermakna Nabi kita tercinta tidak menggunakan kata kafir kepada penduduk Madinah yang tidak memeluk Islam. Sebab bagi Nabi, hal demikian sangat sensitif dan bisa menggagalkan misinya untuk mempersatukan penduduk Madinah masa itu --dan yang lebih dari itu adalah sebagai bukti bahwa nabi Muhammad SAW begitu sangat tinggi rasa cinta kasihnya pada seluruh penduduk Madinah serta dapat menjadi pelajaran berharga bagi umat manusia sampai yaumil kiamah.

Ditengah masyarakat sering kita mendengar kata kafir (oknum atau kelompok tertentu) seringkali digunakan untuk melabeli kelompok atau individu yang bertentangan dengan ajaran yang mereka yakini, kepada non-Muslim, bahkan tidak jarang juga pelabelan tersebut disematkan terhadap sesama Muslim itu sendiri.

Itulah ending akhir Bahtsul Masail NU memutuskan baiknya tidak menggunakan kata kafir bagi Non-Muslim di Indonesia yang merupakan negara kita tercinta yang plural ini. Karena disadari atau tidak, kata kafir memang sungguh menyakiti sebagian kelompok non-Muslim yang dianggap mengandung unsur kekerasan teologis.

Hasil Munas NU 2019 akhirnya menyepakati tidak menggunakan kata kafir, akan tetapi menggunakan istilah muwathinun, yaitu warga negara (national state). Hal demikian agar bermakna setara antara status Muslim dan Non-Muslim di dalam sebuah negara tercinta kita ini. 
Adanya keputusan Munas NU tersebut bukan berarti menghapus kata kafir seperti yang termuat dengan jelas dalam Al-Qur'an. Hanya saja penyebutan kata kafir terhadap non-Muslim di Indonesia rasanya tidak bijak, seperti halnya juga yang pernah dicontohkan oleh Rasul kita dalam piagam madinah. Dirujuk oleh para funding father bangsa kita dalam konsep bagus yang kita kenal dengan nama Pancasila. Toh kenyataannya bangsa kita tercinta ini dirancang oleh beragam suku, ras, serta agama berbeda, tidak hanya Islam.

Tujuan mulianya adalah tidak memberikan atribusi teologis yang diskriminatif dalam tanda petik kepada sekelompok warga negara lain yang notabenenya bukan beragama Islam.

Kalau meminjam kata KH. Ma'ruf Kozim selaku Dewan Pakar Aswaja Center PWNU Jawa Timur menyebutkan bahwa terminologi dalam kitab Fiqih kita ada Darul Islam dan Darul Kuffah. Makna warga negara dalam Darul Islam ada beberapa sebutan, diantaranya:

1. Kafir Harbi, yaitu orang yang memerangi islam dan boleh diperangi.

2. Kafir Dzimmi, yaitu orang yang membayar jizyah untuk mendapatkan perlindungan. Tidak boleh diperangi.

3. Kafir Mu'ahad, yaitu orang yang melakukan perjanjian damai dalam beberapa tahun. Tidak boleh diperangi.

4. Kafir Musta'min, yaitu orang yang meminta perlindungan. Tidak boleh diperangi.

Salahsatu Keputusan Munas NU yang mengatakan bahwa Non Muslim di Indonesia tidak ada yang memenuhi kriteria seperti yang telah disebutkan dalam 4 point diatas. Sehingga pemaknaan Non Muslim disebut Warga Negara (muwathinun / national state).

Ulasan diatas, tidak bermaksud menggurui, hanya saja sebagai sekilas jawaban dari kegelisahan pribadi, dan mudah-mudahan dapat menjadi referensi tambahan agar kita semakin kuat menebarkan rasa cinta kasih kita kepada tidak hanya sesama umat Islam, Non Muslim pun demikian, bahkan kepada alam semesta. Agar terwujud tujuan akhir Islam, yakni menjadi Agama yang rahmatan lil alamiin. Aamiin. 
"Non Muslim Jangan Disebut Kafir, Sebut Saja Muwathinun (Warga Negara)"

Wallahu a'lam bish-shawabi.

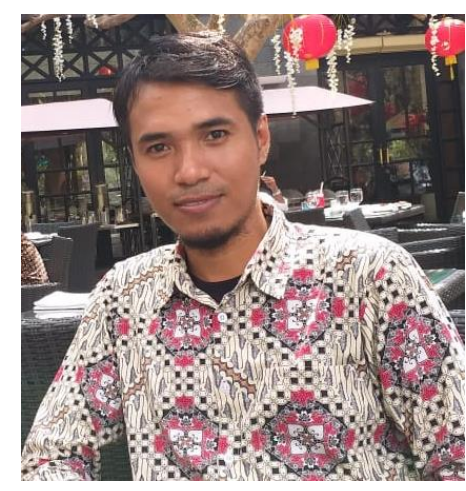

Penulis : M. Jamil, S.H.

Ketua Umum Pusat Studi Mahasiswa Pascasarjana (PUSMAJA) Mbojo-Yogyakarta Periode 2015-2017 | Ketua II Bagian Eksternal Dewan Pimpinan Cabang Perhimpunan Mahasiswa Hukum Indonesia Daerah Istimewa Yogyakarta (DPC PERMAHI DIY) Periode 2012-2014 | Ketua Ikatan Keluarga Alumni Prodi Ilmu Hukum Fakultas Syariah dan Hukum UIN SunanKalijaga Yogyakarta (IKASUKA Ilmu Hukum) Periode 2018-2023.

\section{Ful Sumber Tulisan:}

M. Jamil, "Non Muslim Jangan Disebut Kafir, Sebut Saja Muwathinun (Warga Negara)", dimuat di http://ikasukaih.uin-suka.ac.id/id/kolom/detail/162/nonmuslim-jangan-disebut-kafir-sebut-saja-muwathinun-warga-negara, pada 4 Maret 2019. 